DOI https://doi.org/10.30525/978-9934-26-147-3-8

\title{
МЕМОРАНДУМ ЯК ПРАВОВИЙ ІНСТРУМЕНТ ВЗАСМОДІЇ ОРГАНІВ ПУБЛІЧНОЇ ВЛАДИ $З$ МІЖНАРОДНИМИ ОРГАНІЗАЦІЯМИ У СФЕРІ ЗАПОБІГАННЯ ТА ПРОТИДІЇ ДОМАШНЬОМУ НАСИЛЬСТВУ
}

\author{
Король Н. П. \\ керівник апарату Вінницького апеляційного суду \\ м. Вінниця, Украӥна
}

Етика ненасильства як базова цінність цивілізаційного розвитку будь-якої країни $\epsilon$ пріоритетним завданням гуманітарної складової безпеки суспільного життя, розбудови відкритого і стабільного громадянського суспільства в об'єднаній Європі.

Протягом останніх років Україна значно просунулась у створенні системи запобігання та протидії домашньому насильству. Завдяки наполегливій та ефективній співпраці органів публічної влади, міжнародних інституцій, громадянського суспільства ухвалено важливі нормативні акти, які фактично створюють фундамент для розбудови чіткої системи протидії насильству.

Україна, в ході формування національного законодавства, досліджує i адаптує положення міжнародних стандартів 3 прав людини, у тому числі щодо протидії домашньому насильству $[1$, с. 6].

У 2017 році ухвалено Закон України «Про запобігання та протидію домашньому насильству», а на його основі значний обсяг нормативних актів. Зокрема, створено та прийнято Концепцію Державної соціальної програми запобігання та протидії домашньому насильству та насильству за ознакою статі на період до 2025 року, Типові положення про притулок для постраждалих осіб і мобільні бригади соціально-психологічної допомоги. Наразі відбувається активна робота 3 їх практичного впровадження на всіх рівнях зі збереженням базових принципів та міжнародних підходів до надання комплексної допомоги в ситуаціях домашнього та гендерно зумовленого насильства.

Указом Президента України «Про невідкладні заходи із запобігання та протидії домашньому насильству, насильству за ознакою статі, захисту прав осіб, які постраждали від такого насильства» від 21 вересня 2020 року № 398/2020, серед іншого, передбачено забезпечення додаткових процесуальних гарантій неповнолітнім особам при проведенні їх допиту, опитування під час кримінального провадження, що базуються на найкращих міжнародних практиках, зокрема на моделі «Barnahus».

Укладено Меморандум про взаєморозуміння 3 питань сприяння впровадженню моделі Барнахус в Україні між Уповноваженим Верховної Ради України з прав людини, Уповноваженим Президента 
України з прав дитини, Верховним Судом, Офісом Генерального прокурора, Міністерством юстиції України, Міністерством внутрішніх справ України, Міністерством соціальної політики України, Міністерством охорони здоров'я України, Національною поліцією України, Координаційним центром з надання правової допомоги та Представництвом Дитячого фонду ООН (ЮНІСЕФ) в Україні (далі - Меморандум).

Проєкт «Впровадження моделі Барнахус для захисту дітейпостраждалих від насильства» за підтримки представництва Дитячого фонду ООН (ЮНІСЕФ) в Україні має на меті захист прав дітей, які $є$ потерпілими чи свідками в кримінальних провадженнях щодо кримінальних правопорушень, пов'язаних 3 насильством, i передбачає скоординовану взаємодію членів міждисциплінарної команди 3 метою проведення процесуальних дій відповідно до положень Кримінального процесуального кодексу України в середовищі дружньому до дитини та в умовах, які мінімізують наслідки іiї травматизації та надання таким дітям комплексної соціальної, психологічної, правової, медичної інших видів допомоги.

Отже, пріоритетним напрямом стає співробітництво з авторитетними міжнародними організаціями, що дозволяе задіяти багатосторонні механізми взаємодії.

Продуктивність співробітництва органів публічної влади 3 міжнародними організаціями, серед іншого, у сфері запобігання домашньому насильству, значною мірою залежить від досконалості інституційної та договірної форм взаємин. Механізми співробітництва залежать від правової природи кожної з сторін і принципів їх взаємодії, визначаються призначенням та особливостями правозастосування.

Так, укладений Меморандум розглядається як основа для подальшого розвитку взаємодії та співробітництва Сторін у межах повноважень, визначених чинним законодавством. Меморандум фіксує наміри Сторін надавати одна одній всебічну та повну підтримку для розвитку співробітництва. У рамках Меморандуму Сторони підтвердили свою згоду на співпрацю через надання взаємної організаційної та технічної підтримки, упровадження кращих практик в організації та проведенні навчальних заходів для спеціалістів, проведення спільних заходів тощо.

Разом 3 тим, Меморандум не створює жодних фінансових та правових зобов'язань для Сторін. В даному випадку відносини, які унормовано в такий спосіб, не врегульовані на правовому рівні i, відповідно, укладений меморандум в даному випадку є лише пам'ятною запискою, і не набуває правової природи.

Таким чином, зважаючи на вищезазначене, меморандум не породжує юридичних зобов'язань, а лише призначений для визначення понять та фіксації намірів сторін-учасників. В зв'язку $з$ цим, виникає питання щодо ефективності та дієвості такого правового інструменту взаємодії, зокрема в публічній сфері. 
3 огляду на останні тенденції в Україні й зацікавленість уряду у просуванні вирішення проблем домашнього насильства, зокрема шляхом покращення нормативно-правової бази, при регулюванні договірних відносин публічної сфери виникає необхідність приділення більшої уваги саме характеристиці меморандуму та правомірності використання такого поняття.

Меморандум - дипломатичний документ, у якому викладаються погляди уряду або урядів 3 якого-небудь питання [2, с. 363]. Меморандум (un mémorandum) $є$ засобом комунікації, який використовується урядом для викладу фактів або правової ситуації. Він містить стислий виклад стану питання та обгрунтування офіційної позиції держави [3, с. 112].

Можна продовжувати наводити й інші тлумачення даного поняття, адже доктринальні, довідкові та навчальні джерела надають можливість скласти загальне враження про меморандум, але не містять критеріїв, характеристик, які дали можливість перетворити меморандум у дієвий i ефективний правовий інструмент взаємодії щодо вирішення суспільноважливих питань.

Відповідно, не дивлячись на поширеність застосування у взаєминах між органами публічної влади та міжнародними організаціями поняття «меморандуму», останнє на сьогодні потребує грунтовного дослідження на предмет доцільності та ефективності використання такого правового інструменту регулювання договірних відносин.

\section{Література:}

1. Галай А. О., Галай В. О., Головко Л. О., Муранова В. В. Міжнародний досвід попередження та протидії домашньому насильству : Монографія. За заг. ред. А. О. Галая. Київ: КНТ, 2014. 160 с.

2. Бибик С. П., Сюта Г. М. Словник іншомовних слів: тлумачення, словотворення та слововживання / За ред. С. Я. Срмоленко. Харків: Фоліо, 2006. 623 c. URL : https://nmetau.edu.ua/file/126.pdf.

3. Мартынюк О. Н. Особенности дипломатической переписки (на материале французского языка) Науковий вісник Міжнародного гуманітарного університету. Сер.: Філологія. 2019. № 38. том 2. URL : https://evnuir.vnu.edu.ua/bitstream/123456789/16360/1/Martyniuk_ mgu_2019.pdf.

4. Завальна Ж. В. Договір чи меморандум: бути чи здаватись? Форум права. 2015. № 2. C. 52-57. URL: http://nbuv.gov.ua/j-pdf/FP_index.htm_ 2015_2_10.pdf.

5. Про невідкладні заходи із запобігання та протидії домашньому насильству, насильству за ознакою статі, захисту прав осіб, які постраждали від такого насильства : Указ Президента України від 21.09.2020 p. № 398/2020. URL : https://www.president.gov.ua/documents/ 3982020-35069.

6. Меморандум про взаєморозуміння 3 питань сприяння в провадженню моделі Барнахус в Україні між Уповноваженим Верховної 
Ради України з прав людини, Уповноваженим Президента України 3 прав дитини, Верховним Судом, Офісом Генерального прокурора, Міністерством юстиції України, Міністерством внутрішніх справ України, Міністерством соціальної політики України, Міністерством охорони здоров’я України, Національною поліцією України, Координаційним центром 3 надання правової допомоги та Представництвом Дитячого фонду ООН (ЮНICЕФ) в Україні. URL : https://cutt.ly/ DED7HoR.

DOI https://doi.org/10.30525/978-9934-26-147-3-9

\section{ГРОМАДСЬКИЙ МОНІТОРИНГ ЯК МЕХАНІЗМ ФОРМУВАННЯ ЕФЕКТИВНОЇ ЛОКАЛЬНОЇ ПОДАТКОВОЇ ПОЛІТИКИ}

Крушельницька Т. А. доктор наук з державного управління, професор, професор кафедри державного управління і місчевого самоврядування Національного технічного університету «Дніпровська політехніка»

\section{Гуржій О. В.}

аспірант кафедри державного управління і місиевого самоврядування Національного технічного університету «Дніпровська політехніка»

\section{Перетятько О. I.}

аспірант кафедри державного управління і місиевого самоврядування Національного технічного університету "Дніпровська політехніка» м. Дніпро, Україна

В умовах економічної невизначеності, а тим більше в умовах загострення економічної кризи через окупацію Криму, ведення бойових дій на сході Донбасу, пандемію i заходи протидії поширенню коронавірусої хвороби (COVID-19), податкова політика залишається фундаментальним інструментом стимулювання національної економіки, впливу на зміну економічного стану країни в цілому і іiі територій. Саме економічна криза сформувала потребу у застосуванні додаткових механізмів публічного управління, у тому числі податкових, для підтримки громадян і суб'єктів підприємницької діяльності. В цих умовах реалізація податкової політики набула нових властивостей, які підвищили значущість формування податкової політики на місцевому 